University of Nebraska - Lincoln

DigitalCommons@University of Nebraska - Lincoln

Publications, Agencies and Staff of the U.S.

Department of Commerce

U.S. Department of Commerce

1999

\title{
Baleen Whales: Conservation Issues and The Status Of The Most Endangered Populations
}

Phillip Clapham

Sharon Young

Robert L. Brownell Jr.

Southwest Fisheries Science Center, rlbcetacea@aol.com

Follow this and additional works at: https://digitalcommons.unl.edu/usdeptcommercepub

Part of the Environmental Sciences Commons

Clapham, Phillip; Young, Sharon; and Brownell, Robert L. Jr., "Baleen Whales: Conservation Issues and The Status Of The Most Endangered Populations" (1999). Publications, Agencies and Staff of the U.S.

Department of Commerce. 104.

https://digitalcommons.unl.edu/usdeptcommercepub/104

This Article is brought to you for free and open access by the U.S. Department of Commerce at DigitalCommons@University of Nebraska - Lincoln. It has been accepted for inclusion in Publications, Agencies and Staff of the U.S. Department of Commerce by an authorized administrator of DigitalCommons@University of Nebraska - Lincoln. 


\title{
Baleen whales: conservation issues and the status of the most endangered populations
}

\author{
PHILLIP J. CLAPHAM, SHARON B. YOUNG* and ROBERT L. \\ BROWNELL, JR † \\ National Marine Fisheries Service, Northeast Fisheries Science Center, \\ 166 Water Street, Woods Hole, MA 02540, USA \\ *Humane Society of the United States, 22 Washburn Street, Bourne, MA 02532, USA \\ $\dagger$ National Marine Fisheries Service, Southwest Fisheries Science Center, \\ La Jolla, CA 92038, USA
}

\section{CONTENTS}

ABSTRACT

INTRODUCTION 36

BALEEN WHALES $\quad 36$

$\begin{array}{ll}\text { Classification and general characteristics } & 36\end{array}$

$\begin{array}{ll}\text { Conservation issues } & 37\end{array}$

$\begin{array}{ll}\text { Entanglement and fisheries issues } & 37\end{array}$

$\begin{array}{ll}\text { Ship strike } & 38\end{array}$

Whaling $\quad 38$

$\begin{array}{ll}\text { Pollution and disease } & 39\end{array}$

Habitat degradation $\quad 39$

$\begin{array}{ll}\text { Summary } & 40\end{array}$

$\begin{array}{lr}\text { MOST ENDANGERED POPULATIONS } & 40\end{array}$

Northern Right Whale $\quad 41$

Bowhead Whale $\quad 44$

Gray Whale $\quad 46$

Blue Whale $\quad 47$

OTHER SPECIES $\quad 50$

Humpback Whale $\quad 50$

Southern Right Whale $\quad 51$

OTHER ISSUES $\quad 52$

$\begin{array}{ll}\text { Small population problems } & 52\end{array}$

Analysis of whaling data $\quad 53$

ACKNOWLEDGEMENTS

REFERENCES $\quad 56$

\begin{abstract}
Most species of baleen whales were subject to intensive overexploitation by commercial whaling in this and previous centuries, and many populations were reduced to small fractions of their original sizes. Here, we review the status of baleen whale stocks, with an emphasis on those that are known or thought to be critically endangered. Current data suggest that, of the various threats potentially affecting baleen whales, only entanglement in fishing gear and ship strikes may be significant at the population level, and then only in those populations which are already at critically low abundance. The impact of some problems (vessel harassment, and commercial or aboriginal whaling) is at present probably minor. For others (contaminants, habitat degradation, disease), existing data either
\end{abstract}


indicate no immediate cause for concern, or are insufficient to permit an assessment. While the prospect for many baleen whales appears good, there are notable exceptions; populations that are of greatest concern are those suffering from low abundance and associated problems, including (in some cases) anthropogenic mortality. These include: all Northern Right Whales Eubalaena glacialis, Bowhead Whales Balaena mysticetus of the Okhotsk Sea and various eastern Arctic populations, western Gray Whales Eschrichtius robustus, and probably many Blue Whale Balaenoptera musculus populations. We review the status of these populations and, where known, the issues potentially affecting their recovery. Although Humpback Whales Megaptera novaeangliae and Southern Right Whales Eubalaena australis were also heavily exploited by whaling, existing data indicate strong recovery in most studied populations of these species.

Keywords: baleen whales, Right Whale, Bowhead Whale, Gray Whale, Blue Whale, Humpback Whale, conservation.

\section{INTRODUCTION}

A decade has now passed since passage of the International Whaling Commission's (IWC) moratorium on commercial whaling. Although the exploitation of whales has continued to some extent under the convention's provisions for scientific research (and, more recently, under 'objection' by Norway), commercial whaling on the scale that was practised for most of this century is currently a thing of the past. That scale, however, was often immense. In the Antarctic alone, more than 2 million whales were killed, reducing the large Southern Ocean populations to small fractions of their original size. Recent revelations of widespread illegal catches by the Soviet Union (Yablokov, 1994; Zemsky et al., 1995; Zemsky, Mikhaliev \& Berzin, 1996; Yablokov et al. 1998) have shown that the overexploitation was greater than once thought; indeed, the Soviets took in excess of 100000 more whales in the Antarctic than they reported to the IWC, including protected and already depleted species such as Southern Right Eubalaena australis, Humpback Megaptera novaeangliae and Blue Whales Balaenoptera musculus and B. m. brevicauda. Figures for the true extent of Soviet activities in the northern hemisphere have yet to emerge; although it is known that total catches there were considerably less than in the Antarctic, the impact on some critically endangered populations (such as Northern Right Whales Eubalaena glacialis) was considerable.

Our knowledge of the present status of the world's baleen whales varies considerably from species to species. In some populations, it is apparent that recovery is proceeding strongly; by contrast, it is clear that certain others remain highly endangered. For some, knowledge is insufficient to assess their conservation status. Overall (and despite a persistent public perception that all large whales remain threatened by extinction), the prospect for the majority of populations is probably reasonably good. There are, however, some notable exceptions. Here, we review issues that potentially affect baleen whales, and attempt to assess the status of those species or populations which are most in need of conservation action.

\section{BALEEN WHALES}

\section{Classification and general characteristics}

The baleen whales (Order Cetacea, suborder Mysticeti) are currently considered to comprise 11 species (Mead \& Brownell, 1993). Elements of the present classification have been contested in light of recent genetic analyses: for example, species-level differences reflecting protracted isolation of populations have been claimed for North Pacific and Antarctic Minke Whales (Balaenoptera acutorostrata; Wada \& Numachi, 1991), and for different forms of the Bryde's Whale (B. edeni; A. Dizon, unpublished data). However, while some taxonomic revision appears inevitable, from the standpoint of this review such reclassification is largely irrelevant. 
The 11 species are currently grouped into four families (Mead \& Brownell, 1993), which are listed below. (i) Balaenopteridae (also called the rorquals): six species, including the Blue, Fin Balaenoptera physalus, Minke, Sei B. borealis, Bryde's and Humpback Whale. The so-called Pygmy Blue Whale Balaenoptera musculus brevicauda is currently assigned subspecific status (Ichihara, 1966). (ii) Balaenidae: the Northern Right Whale, Southern Right Whale, and the Bowhead Balaena mysticetus. (iii) Eschrichtiidae: the Gray Whale Eschrichtius robustus. (iv) Neobalaenidae: the Pygmy Right Whale Caperea marginata, a southern hemisphere species about which virtually nothing is known. It will therefore not be mentioned further here; it has rarely been exploited, and there is no reason to suspect that its conservation status is a concern.

Mysticetes are all characterized by the presence in the mouth of several hundred plates of baleen, with the number and type varying among species. The baleen forms an elaborate filtration system which enables the whales to strain prey from large volumes of seawater. Mysticetes are found in a variety of coastal, shelf and pelagic habitats, and are not (relative to some toothed whales) deep divers. They take a variety of prey. With the exception of the Blue Whale, which subsists almost entirely upon euphausiids (krill), the rorquals are generalists that eat krill and various species of small schooling fish (Gaskin, 1982). Right Whales are exclusively planktivorous, notably on copepods (Mayo \& Marx, 1989; Wishner et al., 1995). Gray Whales are primarily but not exclusively benthic feeders whose diet is predominantly amphipods (Nerini, 1984). Bowheads utilize a variety of invertebrate prey, notably copepods and euphausiids (Lowry, 1993). Baleen whales have a gestation period which ranges from approximately 10 to 13 or 14 months; in most species it appears to be slightly less than a year (Lockyer, 1984). In all species, females are somewhat larger than males (Ralls, 1976). General information on the biology and behaviour of all mysticetes is concisely summarized in Leatherwood \& Reeves (1983).

Most species of baleen whales undertake extensive seasonal migrations between cold, productive summer feeding grounds in temperate or high latitudes, and winter mating and calving areas in tropical or warm temperate waters (Kellogg, 1929; Mackintosh, 1942). Migration patterns vary considerably within and among species, but it is important to recognize that high mobility and frequent movement across international boundaries is a common feature of most mysticetes. The exception is the Bryde's whale, which may be at least two separate species, each with its own ecology and life history patterns; at least two forms appear to remain in tropical waters year-round, and one is not (unlike all other mysticetes) a seasonal breeder (Best, 1977).

\section{Conservation issues}

There are several threats which potentially affect some or all large whale species, with the incidence and degree of impact varying considerably by population. Where relevant, specific details are provided in the section on threatened populations (below), but a brief description of each issue is given here as background. All other things being equal, specific problems will pose a greater threat to populations which are already vulnerable due to small size and associated factors.

\section{Entanglement and fisheries issues}

Entanglement in fishing gear of various types is a major source of non-natural mortality in marine mammals (see the many papers collected in Perrin, Donovan \& Barlow 1994). Small cetaceans and pinnipeds are particularly vulnerable because their small size makes it likely that, once entrapped, they will be unable to free themselves and will thus quickly drown. By contrast, the larger baleen whales are often capable of dragging fishing gear away with them, but a serious entanglement will often diminish the animal's ability to feed and will thus lead to a protracted death from starvation.

The incidence of entanglement varies considerably by area and by species. Coastal species which live in heavily fished regions are especially vulnerable (e.g. Humpback and Right Whales off 
the eastern seaboard of the United States; Kraus, 1990; Volgenau, Kraus \& Lien 1995). Whales can become entangled in gear of many types, including long line, drift nets, lobster trap lines and even mid-water trawls; however, the largest problem lies with gill nets, which have proliferated throughout much of the world's oceans in the last 30 years (Perrin et al., 1994).

Large whale species known to be most affected by entanglement are Northern Right and Humpback Whales (Kraus, 1990 and Lien, 1994, respectively). The extent to which this problem threatens populations of large whales is unclear; it may not represent a significant conservation issue for most species, although the Right Whale is clearly an exception (see below). It is possible that other populations at low levels of abundance are significantly impacted by entanglement mortalities, but data are generally lacking. Whale disentanglement programs are maintained only on the east coast of North America and in Oman.

The extent to which human overexploitation of commercial fish stocks negatively impacts large whales is difficult to determine. Apparent changes in ecosystem dynamics precipitated by overharvesting of finfish has presumably affected large whales in certain areas. An example is the Gulf of Maine, where virtual extirpation of the Georges Bank stock of Atlantic herring Clupea harengus by the Distant Water Fleet in the early 1960s (Brown \& Halliday, 1983) presumably removed a substantial prey resource that had previously been available to local balaenopterid populations. P. M. Payne et al. (1990) have suggested that this exploitation substantially changed the ecosystem dynamics and feeding habits of mysticetes in the region. However, whether such perturbations result in diminished reproductive success is unknown.

\section{Ship strike}

All whales are potentially subject to collisions with ships, and incidents have been reported anecdotally with most species (e.g. Kraus, 1990; Barlow et al., 1995). Fast commercial vessels such as container ships are a particular threat. Strikes by large vessels are invariably fatal; whales may also be injured, sometimes severely, by collisions with pleasure craft, an increasing hazard in habitats adjacent to highly developed coastline. The most vulnerable species are inevitably those that are slow, or that spend much time at the surface, or that utilize habitats in the vicinity of major shipping lanes. Unfortunately, as noted below, the critically endangered North Atlantic Right Whale qualifies in all three categories.

\section{Whaling}

Whaling today continues in three basic forms. Aboriginal/subsistence takes occur in various places and on a variety of species. Examples are the Inuit hunt for Bowheads in the western Arctic,* the occasional taking of Humpback Whales off the Caribbean island of Bequia, the Russian aboriginal catch of Gray Whales, and the killing of Fin and Minke Whales by native Greenlanders (see IWC, 1996, pp. 139-146). The four preceding are all regulated by the IWC. Other aboriginal takes are not. Some, like the traditional hunt for either Sperm Whales Physeter macrocephalus or Bryde's Whales in Indonesia (Barnes, 1991), are reasonably well documented. Others, such as a suspected hunt for Humpbacks off the remote island of Pagalu off equatorial West Africa (Aguilar, 1985) remain uninvestigated. With the possible exception of a recently initiated Inuit hunt for eastern Arctic Bowheads in Canada (see below), there is no reason to believe that aboriginal operations are significantly impacting any population of great whales, but this belief must be considered tentative in the absence of catch and biological data from certain areas.

With the exception of the present annual take of several hundred north-eastern North Atlantic

*Our inclusion of 'eastern' and 'western' Arctic in this paper is based upon the common use of these terms to describe Bowhead Whale populations. We recognize, however, that (as the Arctic Ocean is circumpolar) this usage reflects a purely North American geographical perspective. 
Minke Whales under objection by Norway, commercial whaling per se is not currently practised. Catches for scientific research continue, with Japan taking several hundred Antarctic and North Pacific Minke Whales each year.

Recently, molecular genetic techniques have been used to determine the species identity of meat sampled in Japanese markets or impounded by customs officials (Baker \& Palumbi, 1994). These analyses have illuminated what appears to be illegal trade in whale meat, an issue that regained prominence in April 1996 when several tons of smuggled Minke Whale meat from Norway were impounded in Japan. The political implications of this trade are certainly important to the issue of commercial whaling, as they raise serious questions regarding enforcement procedures and the ability of a country or company to circumvent regulations protecting large whales. However, there is currently no evidence to suggest that these activities are extensive, or that they involve critically threatened populations. Furthermore, it is known that some of the 'illegal' products in Japanese markets come from locally stranded animals, which are very valuable given the high price of whale meat.

\section{Pollution and disease}

The impact of pollution on large whales is debatable. The subject is reviewed by O'Shea \& Brownell (1994), who conclude that there is currently no evidence for significant contaminant-related problems in baleen whales. Although much more research needs to be conducted, existing data on mysticetes support the view that the lower trophic levels at which these animals feed should result in smaller contaminant burdens than would be expected in many odontocetes, which typically show burdens that differ from those of baleen whales by an order of magnitude (O'Shea \& Brownell, 1994). There is currently no evidence for any of the problems that have been linked to excessive contaminant burdens in some terrestrial mammals, such as reproductive failure or immune system suppression (e.g. Mink Mustela vison; Kihlström et al., 1992). However, the manner in which pollutants negatively impact animals is complex and difficult to study, particularly in taxa (such as large whales) for which many of the key variables and pathways are unknown (Aguilar, 1987; O'Shea \& Brownell, 1994). A more plausible potential problem is that of transgenerational accumulation (Colborn \& Smolen, 1996), but this remains unstudied in baleen whales or any other cetacean. The issue of pollution and cetaceans was the subject of an IWC workshop held in 1995 (IWC, 1996, pp. 32-33).

Unlike in some dolphins and pinnipeds, there have been no recorded epizootics in baleen whales. The only known case of a mass mortality was that of Humpback Whales in the southern Gulf of Maine in 1987/88. Geraci et al. (1989) provide strong evidence that these deaths resulted from consumption of mackerel whose livers contained high levels of saxitoxin, a red-tide toxin, the origin of which remains unknown. It has been suggested that red tides are somehow related to increased freshwater runoff from coastal development, a link that has led some observers to suggest that such events may become more common among marine mammals. However, lack of relevant data (and the absence of additional mortalities) precludes further speculation.

\section{Habitat degradation}

Terrestrial mammals must often compete with a burgeoning human population for space. Because humans do not permanently colonize marine environments, habitat loss (in the strict sense of the term) is not a serious issue for most large whales. The exceptions are those which are dependent upon restricted waters adjacent to highly developed coastline, such as the North Atlantic Right Whale and Grey Whale. In such areas, habitat degradation is a potentially serious issue (Clapham \& Brownell, 1999).

Probably the most dramatic source of recent habitat degradation for baleen whales is spilt oil. The Exxon Valdez spill, although not the world's largest, was one of the most significant in that it 
occurred in an area rich in resources for numerous marine mammals (Loughlin, 1994a). Data on the effects of oil pollution on cetaceans are inconclusive, and the large baleen whales appear to be generally unaffected by oil per se (Geraci, 1990; Loughlin, 1994b). Loughlin (1994b) attributed the finding of 26 Gray Whale carcasses following the Exxon Valdez spill to natural mortality in combination with increased observer effort, but as no necropsies were performed on these animals this interpretation must be considered inconclusive. General concerns with regard to oil pollution are ingestion of contaminated prey, potential irritation of skin and eyes, inhalation of toxic fumes, and abandonment of polluted feeding habitat (Geraci \& St. Aubin, 1980; Geraci, 1990). As noted below, this, and the potential for behavioural disruption from petrochemical operations generally, is a particular concern in at least one population, the western Gray Whale.

In addition to contaminants and red tide events, noted above, the potential for habitat degradation comes from a variety of sources. The effect on critical behaviours (foraging, mating, nursing, etc.) of noise pollution from shipping or oil and gas development is unclear, although various observations suggest that marine mammals can habituate well to even quite high levels of sound (Geraci \& St Aubin 1980). Playback experiments on Gray and Bowhead Whales indicate that the animals will actively avoid a very loud sound source (Malme et al., 1983), but whether real-life sources (such as drilling platforms) negatively impact behaviour to the point that it diminishes reproductive success is unclear.

There is some evidence that increased pleasure boat traffic disrupts behaviour. Such craft as parasails, jet skis and fast power boats can pose a threat to whales even if their operators have no interest in the animal itself. In some areas, whales are observed with prominent propeller scars resulting from collisions with small boats (Seipt et al., 1990). There is some indication that Humpback Whales avoid areas with high pleasure craft traffic off Maui (Glockner-Ferrari \& Ferrari, 1990). Other problems can arise from vessels whose operations are directed at the whales themselves, i.e. whalewatching from either commercial or private vessels. There can be little doubt that large-scale unregulated whalewatching, involving numerous boats circling and pursuing a whale, will temporarily disrupt behaviours such as courtship and nursing. The impact of such harassment on the reproductive success of individuals is unknown.

\section{Summary}

The primary concern of conservation managers is of course those problems which are likely to impact a species at the level of the population rather than of the individual, although the former may be affected if the reproductive success of many individuals is diminished. There are numerous issues of potential concern to whale conservation. While we strongly caution that lack of data and lack of impact are not necessarily synonymous, there is currently little evidence to suggest that most of these issues are resulting in major negative impacts at the population level. The probable exceptions, for some already small and endangered populations, are ship strikes, and entanglement in fishing gear. In addition, serious habitat degradation and concommitant impacts on prey from oil spills are of potential concern for some small populations. Inevitably, populations which have been reduced to small sizes by commercial whaling (i.e. those described below) will be more vulnerable to these various threats than others. Specific details are given below.

\section{MOST-ENDANGERED POPULATIONS}

Populations at high risk of extinction are considered here to be those for which abundance is known or thought to be very low (considerably fewer than a thousand individuals); these are listed in Table 1. Our use of terms such as 'critically endangered' (e.g. for Northern Right Whales) reflects a subjective judgement of status based upon the best information currently available. These judgements are made for the purpose of this paper and do not necessarily reflect criteria employed by 
Table 1. The most endangered populations of baleen whales

\begin{tabular}{|c|c|c|c|}
\hline Species & Population & Abundance & Lack of recovery due to: \\
\hline Northern Right & Eastern North Pacific & tens? & recent hunting \\
\hline \multirow[t]{3}{*}{ Whale } & Western North Pacific & low hundreds? & recent hunting \\
\hline & Eastern North Atlantic & extinct? & wiped out by hunting $c .1900$ \\
\hline & Western North Atlantic & about 300 & anthropogenic mortality? \\
\hline \multirow[t]{3}{*}{ Bowhead Whale } & Davis Strait/Hudson Bay & $450+$ & recovery status unclear \\
\hline & Spitsbergen/Barents Sea & tens? & intensive historical whaling \\
\hline & Okhotsk Sea & low hundreds & recent hunting \\
\hline Gray Whale & Korea/Okhotsk Sea & $250 ?$ & recent hunting \\
\hline Blue Whale & $\begin{array}{l}\text { All except eastern North Pacific } \\
\text { and perhaps eastern North Atlantic }\end{array}$ & unknown & recovery status unclear \\
\hline
\end{tabular}

international agencies such as the International Union for the Conservation of Nature and Natural resources (IUCN). The term status is used below to mean abundance, together with the various factors (such as reproduction and mortality) that determine population growth or decline.

It is important to recognize that the estimation of abundance in large whales is exceedingly difficult given the wide-ranging nature of the animals, the opaque and often inhospitable (to humans) environment in which they live, and the fact that they spend most of their lives underwater. Best (1993) makes the often ignored point that apparent abundance of large whales frequently rises with an increase in systematic survey effort. Given that few populations have been the subject of extensive study, we caution that most estimates of abundance for baleen whales should be regarded as highly tentative, and we cite all such estimates here with that caveat in mind.

Although there is considerable disagreement concerning their numbers, Fin, Sei, Minke and Bryde's Whales are generally thought to be abundant throughout much or all of their ranges, and they are not included in this review. Although on present evidence we do not consider any population of Humpback Whale or Southern Right Whales to be critically endangered, both species were heavily exploited, and we briefly discuss their status in a separate section below.

\section{Northern Right Whale Eubalaena glacialis \\ Populations at high risk: all.}

\section{Historical background}

The Northern Right Whale was probably the first large whale to be hunted on a systematic, commercial basis. The species was taken by Basque whalers in the Bay of Biscay at least as early as the eleventh century (Aguilar, 1986). By the late 1500s the Basques had established a substantial fishery off the Labrador coast (Cumbaa, 1986). This was succeeded by intensive shore whaling off New England in the seventeeth and eighteenth centuries, an activity which continued sporadically into the early part of this century. In the eastern North Pacific, right-whaling by American, French and British vessels began in 1835 (Scarff, 1986). There then followed a period of intense exploitation, and within 14 years most whalers had turned their attention to Bowheads. Additional unrestricted whaling in the Sea of Okhotsk and western North Pacific further reduced the population, and by 1900 the Right Whale was considered rare (Scarff, 1991). Although officially protected throughout its range in $1935, \dagger$ it is now known that the Soviets took substantial numbers of these animals in the

$\dagger$ The 1935 Convention for the Regulation of Whaling was not ratified by the Soviet Union; technically therefore the Soviets were free to kill protected species until 1949, when they signed the convention that created the International Whaling Commission. In practice, as is now known, they continued to kill whales indiscriminately for many years after that. 
North Pacific and Sea of Okhotsk into the 1960s (Yablokov, 1994; Brownell et al., 1999). There is no evidence that these illegal catches extended to the North Atlantic.

\section{Biology}

The Right Whale is a slow animal which frequents coastal and shelf habitats. It feeds in temperate or high latitudes in summer, and calves in warmer water in winter. Both the North Atlantic and North Pacific populations are generally thought to consist of two relatively discrete stocks, in the eastern and western portions of each ocean basin.

In the western North Atlantic, the remaining population is largely confined to US and Canadian waters, feeding in the Gulf of Maine and on the Scotian Shelf, and calving in the coastal waters of Georgia and Florida (Kraus et al., 1986; Winn, Price \& Sorenson, 1986). In the North Pacific, Right Whales feed in the Aleutians, Bering Sea, Gulf of Alaska and Sea of Okhotsk (Scarff, 1991). Migratory patterns inferred from historical catch data (Omura, 1958, 1986) as well as recent scattered sightings (e.g. Mori, 1991) suggest that the western North Pacific population breeds in warm East Asian waters. The mating and calving grounds of any remaining eastern North Pacific animals are unknown. As noted by Scarff $(1986,1991)$, the assumption that the west coast of North America once hosted substantial numbers of wintering Right Whales is not supported by historical evidence. Based upon nineteenth century whaling catch data, Scarff $(1986,1991)$ proposed that many North Pacific Right Whales wintered far offshore, but there is no recent information with which to substantiate this belief.

Female Right Whales become sexually mature between 4 and perhaps 12 years, and produce a single calf on average every 3-4 years (Knowlton, Kraus \& Kenney 1994; Hamilton et al., 1998); this is a significantly slower rate of reproduction than that of the rorquals (Lockyer, 1984). The Right Whale is stenophagous on zooplankton, notably copepods (Mayo \& Marx, 1989). Individual animals can be identified from photographs of the pattern of callosities on the head, and from prominent scarring (Kraus et al., 1986).

The western North Atlantic population has been the subject of a long-term study since the 1970s, and much of its biology and behaviour is reasonably well understood (see Kraus et al., 1986; Kenney, Winn \& Macauley 1994; Knowlton et al., 1994). Most of the population has been biopsy sampled, and genetic analyses are ongoing (Schaeff et al., 1993, 1997; Brown et al., 1994). There is no ongoing field research on this species in either the eastern North Atlantic or anywhere in the North Pacific.

\section{Present status}

The Northern Right Whale is critically endangered throughout its range (reviewed in Brownell, Best \& Prescott, 1986). Given the various problems described below, this species is arguably the most threatened of all baleen whales, and further conservation action is urgently required to avoid its extinction.

In the North Atlantic, the eastern stock appears to be essentially extinct; it is likely that much of the extant population was wiped out by Norwegian whaling at the turn of the century (Collett, 1909). Rare sightings are made of single individuals in European waters (Brown, 1986), but it is not clear whether these represent a tiny remnant population or individuals who have wandered in from the west. Nineteenth-century whaling occurred at Cintra Bay on the coast of West Africa (Reeves \& Mitchell, 1986), and this historical concentration of right whales raised the hope that this area may still be a breeding ground for any remaining eastern North Atlantic animals. A survey in this region in early 1996 failed to find a single whale, although survey conditions were extremely poor (G. Notarbartolo di Sciara, personal communication). Analyses based upon photographs of identified individuals indicate that the present western North Atlantic population numbers $\approx 295$ animals (no confidence limits given; Knowlton et al., 1994); given that the majority of the population appears to 
have been identified, this is likely to represent one of the more accurate estimates of abundance for any large whale. No sustained growth is apparent despite six decades of protection, although the initial post-whaling size of this stock in 1935 is unknown. Recent analysis by Caswell et al. (1999) suggests that the population is actually in decline.

A parallel situation exists in the North Pacific (Brownell et al., 1998). The eastern stock, perhaps irreversibly damaged by recent Soviet illegal catches, is so small that a single sighting merits publication (e.g. Rowntree et al., 1980; Carretta, Lynn \& LeDuc, 1994). With the possible exception of an unconfirmed sighting from the Bering Sea in 1996 (Goddard \& Rugh, 1998), no calf has been observed in the region this century. Recent sighting data show that the western population is more numerous, particularly in the Kuril Islands/Sea of Okhotsk region (Brownell et al., 1999). This group may number in the low hundreds, but no quantitative data are available, and systematic surveys in this area are urgently needed.

Issues

This species appears to suffer from anthropogenic mortalities more than any other. In the western North Atlantic, entanglement in fishing gear and ship strikes are known to have caused numerous Right Whale deaths in recent years, undoubtedly contributing to the apparent failure to recover. Kraus (1990) estimated mortality in the first 4 years of life at between 2 and 17\%, with at least a third attributable to ship collisions and entanglement. Photographs of 118 identified individuals showed that 57\% possessed scarring indicative of entanglement (Kraus, 1990). Fishing gear involved has included gill nets, swordfish drift net and lobster trap lines. Sources of ship strikes are generally unknown, but are primarily large commercial vessels; regrettably, many of the Right Whale's major habitats in the western North Atlantic are adjacent to, or even straddle, major shipping lanes. The population's major calving grounds in the coastal waters of Florida and Georgia have recently been the site of increased military traffic, notably since the closure of several naval bases concentrated activities off the port of Jacksonville. Furthermore, proposed port expansions in the area will only increase the probability of vessel-related mortalities unless mitigating action is taken. At least some of six recorded mortalities during the winter of 1995/96 were attributable to ship strikes; and others could not be conclusively related to US Navy gunnery exercises in the area. Given this population's dependence upon nearshore habitat for much of its life cycle, intensive coastal development in this and other portions of the range poses additional threats to recovery.

Studies showing relatively low genetic diversity in the western North Atlantic population (Schaeff et al., 1991, 1997) suggest that inbreeding may be inhibiting recovery, but this is difficult to interpret without a knowledge of historical genetic structure. The latter topic is currently being investigated using DNA extracted from historical baleen samples (Rosenbaum et al., 1997, 1998). Furthermore, the general issue of inbreeding and its impact on small populations remains controversial (May, 1995; Amos, 1996; Lacy, 1997; and see below).

Little is known of threats to the remaining North Pacific population. Entanglement-related mortality has been documented in the western North Pacific (Kornev, 1994); given the extremely poor survey coverage of this population, it is possible that this is a significant problem.

Overall, the Right Whale's dependence upon a highly abundant but specialized food source (copepods) would presumably make it less adaptable to major environmental change. A Recovery Plan has been produced for Right Whales in US waters by the US National Marine Fisheries Service (National Marine Fisheries Service, 1991). However, there is currently no conservation effort aimed at the North Pacific population despite its critically endangered status. 


\section{Bowhead Whale Balaena mysticetus \\ Populations at high risk: Okhotsk Sea, Eastern Arctic.}

\section{Historical background}

The Bowhead (also called the Greenland Right Whale or Polar Whale) was hunted to commercial extinction in the North Atlantic, beginning in at least the sixteenth century (Ross, 1993). Whalers took this species in Arctic and sub-Arctic latitudes, including off the Labrador coast in the sixteenth century (when the so-called 'Little Ice Age' presumably caused the population's range to shift further south than it occurs today). Commercial whalers began to kill Bowheads in the western Arctic, and later in the Sea of Okhotsk, in the mid-nineteenth century (Bockstoce \& Burns, 1993), and these populations were rapidly depleted. Illegal Soviet catches of Bowheads occurred in the Okhotsk Sea in the 1960s, and the western Arctic population has been exploited under quota since 1978 by Alaskan Eskimos (Stoker \& Krupnik, 1993; Suydam et al., 1995).

\section{Biology}

Thorough reviews of the biology and status of the Bowhead are given by Burns, Montague \& Cowles (1993) and Shelden \& Rugh (1995). The Bowhead has an exclusively northern hemisphere circumpolar distribution, and is closely associated with sea ice (Montague, 1993). Several stocks are recognized (Moore \& Reeves, 1993; Shelden \& Rugh, 1995). Bowheads in the eastern Arctic are divided into three subpopulations, with unknown levels of exchange among them. These are: (i) Hudson Strait, Hudson Bay and Foxe Basin (the Hudson Bay stock); (ii) Davis Strait and Baffin Bay (the Davis Strait stock); and (iii) Spitsbergen and the Barents Sea (the Spitsbergen stock). As noted by Shelden \& Rugh (1995), there is only circumstantial evidence that the Davis Strait and Hudson Bay stocks are separate, but they are currently treated as such to allow for more conservative management. The western Arctic population inhabits the Bering, Beaufort and Chukchi Seas, and appears to comprise a single discrete stock. Finally, there is an apparently separate and historically isolated population in the Sea of Okhotsk. Some exchange between the eastern and western Arctic stocks is indicated from whaling data (Bockstoce \& Burns, 1993), but the frequency of this exchange in modern times is unknown. Segregation by size and sex has been documented in both arctic populations, during the migration as well as at other times (Reeves et al., 1983; Finley, 1990; Angliss et al., 1995).

Bowheads feed on a variety of prey. The most important diet items are copepods and euphausiids, although significant numbers of epibenthic organisms (notably mysids and amphipods) are also taken (Lowry, 1993). It is not known whether Bowheads fast during the winter, but the stomachs of more than half of the whales killed during the spring migration were empty (Lowry, 1993). Migrations are restricted and are dependent upon ice; the species is typically found along the southern edge of pack ice in winter, then moves north as the ice breaks up in spring. In the western Arctic, the winter distribution of the Bowhead encompasses a wide area of the central and western Bering Sea and is associated with the ice front and polynyas (Shelden \& Rugh, 1995). In spring, the whales move north and east along sea ice leads in the Chukchi Sea and on into their principal summering grounds in the Bering Sea.

Calving occurs in spring (April to early June), after a gestation period that may be as long as 1314 months (Nerini et al., 1984; Koski et al., 1993). Weaning occurs between 9 and 15 months after birth (Nerini et al., 1984). Bowheads are slow breeders; recent data suggest that they may not attain sexual maturity until 15-20 years, and females produce a calf every 3 or 4 years thereafter (Koski et al., 1993). However, the species may be exceptionally long-lived: the recent discovery (George et al., 1995), in a large male Bowhead killed by the Alaskan Inuit, of a stone harpoon point of a type not generally in use after 1900 (S. Loring, personal communication), suggests that life expectancy 
can reach 100 years. A similar conclusion has emerged from work based upon stable isotype analysis (Schell, Saupe \& Haubenstock 1989).

Much of our knowledge of this species stems from extensive work conducted on the western Arctic population, due in large part to the continued subsistence hunt and to the requirement for impact studies related to oil and gas exploration in the Alaskan region. With the exception of general sighting surveys in the region (McQuaid, 1986; Christensen, Haug \& Øien, 1992), no research has been conducted on the remnant Barents Sea/Spitsbergen stock. Recent work in the Sea of Okhotsk has been confined to sporadic Russian surveys of the area (e.g. Berzin, Vladimirov \& Doroschenko, 1990), although a joint Russian-US. study of the population characteristics and genetics of Bowheads was begun in the Shantar area in 1995 (Brownell et al., 1997).

\section{Present status}

The slow reproduction and late age at maturation in this species have resulted in relatively low rates of recovery (Koski et al., 1993; Shelden \& Rugh, 1995). However, it is now largely accepted that the western Arctic Bowhead population is recovering slowly from the intensive commercial exploitation to which it was subject. A 1993 survey estimated abundance at 8000 animals (CV 6900-9200); the median estimate of growth over the period 1978-93 was 2.3\% (Zeh, George \& Suydam, 1995). The crude birth rate of this population has been estimated at 0.052 (Koski et al., 1993).

The eastern population is less well known, but is clearly relatively small; estimates by Davis \& Koski (1980) and by Reeves et al. (1983) put the total population at a few hundred. There may be about 250 Bowheads in the Davis Strait population, and 'at least a few tens of whales' in Hudson Bay (Reeves \& Mitchell, 1990). Zeh et al. (1993) suggested that these numbers are conservative and that the two stocks collectively number at least 450 animals. Two recent aerial surveys by Cosens et al. (1997) gave estimates of 256 (CV 31.3) and 284 (CV 48.6) bowheads in northern Foxe Basin. The Spitsbergen/Barents Sea group is observed infrequently nowadays. It is estimated to number 'in the tens of animals', and may be close to extinction (Christensen et al., 1992; Zeh et al., 1993). Belikov et al.'s (1989) suggestion that the population may be slowly recovering was based upon sporadic sightings, including some of questionable reliability. Although the prognosis for this remnant population does not appear good, it should be noted that the relationship among the three eastern substocks (and whether exchange occurs among them) is not clearly understood.

Little is known of the present status of the Okhotsk Sea population, but surveys in the region suggest (without quantitative data) that the population may be in the low hundreds (Berzin et al., 1986, 1990).

Issues

The two populations of concern for this species are those in the eastern Arctic and Okhotsk Sea. The western Arctic Bowhead population requires continued careful monitoring, and remains under threat from possible impacts of disturbance and pollution events associated with extensive oil and gas exploration in Alaskan waters. None the less, its status does not appear to be an urgent conservation issue. The continued aboriginal hunt is well-managed under IWC quota through an agreement between the Alaska Eskimo Whaling Commission and the US National Oceanic and Atmospheric Administration. The current hunt quota is well below the level that would inhibit continued population growth (IWC, 1995; p. 21; Shelden \& Rugh, 1995). No major anthropogenic threats have been identified in the eastern Arctic stock; it is possible that, if this population is failing to recover, the explanation lies primarily with the various problems associated with small population size. However, the killing of two Bowheads from the Hudson Bay population by the Canadian Inuit in the summers of 1994 and 1996 is disturbing in light of the endangered status of this stock and of the precedent that such a catch presumably sets. 
The only known potential threat to the Okhotsk Sea population is impending oil and gas exploration off Sakhalin Island (see below, under the Gray Whale). These activities will be largely concentrated off the east coast of Sakhalin, away from the main Bowhead concentrations off the mainland coast and further north (Berzin et al., 1986); thus, the Bowheads might be less vulnerable to impacts than the western Gray Whale. None the less, this is a cause for some concern, particularly since one of the currently untendered lease areas includes major Bowhead feeding habitat in the Shantar region (Brownell et al., 1997). Coastal development and associated human activities in the western Okhotsk Sea pose another potential threat in the future.

\section{Gray Whale Eschrichtius robustus}

Population at high risk: Western North Pacific/Okhotsk Sea.

\section{Historical background}

The predictable and highly coastal migration of the Gray Whale made it an easy target for shorebased whalers along the western coast of North America (Sayers, 1984). By 1900, the eastern North Pacific population had been reduced to such low numbers that some whalers considered it virtually extinct. Nineteenth-century whaling of various types by Japan, Russia and the United States similarly devastated the population in the western North Pacific and Okhotsk Sea (Henderson, 1984). There appears to have been comparatively little pelagic whaling for this species during the twentieth century: Reeves (1984) documented only 940 Gray Whales taken between 1914 and 1946. It is not clear whether the Soviet Union illegally killed Gray Whales, notably in the western North Pacific, after the species received international protection in 1938, but given the USSR's extensive and indiscriminate activities elsewhere it is hard to see why they would have spared this species if found. The western Gray Whale was considered extinct as late as the early 1970s (Bowen, 1974), but information on catches off Korea and sightings in the Okhotsk Sea showed it to be extant (Brownell \& Chun, 1977; Blokhin, Maminov \& Kosygin 1985).

\section{Biology}

Recently extinct in the North Atlantic (within the last 200 or 300 years, with cause unknown; Mead \& Mitchell, 1984; Bryant, 1995), the Gray Whale today exists only in the North Pacific. It appears to have always had an exclusively northern hemisphere distribution. The Gray Whale is among the most highly migratory of all whales (Mate \& Harvey, 1984), rivalled only by the Humpback Whale in its extensive seasonal movements. Gray Whales migrate annually between high-latitude summer feeding grounds, and mating and calving areas in tropical waters (Kellogg, 1929). The feeding behaviour of this species is quite flexible: it is primarily a bottom-feeder on benthic amphipods, but has been observed to feed in mid-water and at the surface on other prey (Nerini, 1984). It is possible that gestation exceeds 13 months (Rice, 1983), and sexual maturity is attained at an average age of eight years (Rice \& Wolman, 1971).

Two populations are recognized: the eastern North Pacific, also known as the California/ Chukchi stock, and the western North Pacific, known as the Korea/Okhotsk Sea stock. The eastern population feeds in shallow waters in the northern Bering, southern Chukchi and south-western Beaufort Seas, and calves in shallow lagoons along the Pacific coast of the Baja Peninsula (see reviews in Jones, Swartz \& Leatherwood, 1984). The western population appears to summer in the Sea of Okhotsk, and migrates to the mainland coast of Asia; it has been suggested that breeding grounds may exist along the coast of southern China (Henderson, 1990), but this remains uninvestigated. It is not known whether a reliance on coastal lagoons for calving (as is the case for the eastern population) is a characteristic of this species throughout its range. There is no evidence for any interchange between eastern and western populations. 
The accessibility of Gray Whales along the western coast of North American has resulted in extensive research on the eastern population (Jones et al., 1984; Reilly, 1992), and surveys to monitor abundance are ongoing. With the exception of some sporadic Soviet surveys (Blokhin et al., 1985) and a recent study off Sakhalin Island (Weller et al., 1999), no work has been conducted on the western population.

\section{Present status}

The eastern Gray Whale is one of the great success stories in modern endangered species conservation. Having been reduced to perhaps a few hundred animals early this century, it has made a full recovery following international protection in 1938. The current eastern population, which was estimated in 1987/88 at 21113 animals ( $\mathrm{SE}=688$; Reilly, 1992), is considered to have reached preexploitation levels, and is no longer listed as endangered. In contrast, the western population remains very small; its size has been guessed at 250 individuals (Vladimirov, 1994), although no quantitative data are available with which to confirm this estimate (Berzin et al., 1995). None the less, this population is clearly one of the most critically endangered stocks of large whale in the world. As noted by Kato \& Kasuya (1997), Gray Whales continued to be hunted by Korea into the 1960s, and this may have significantly inhibited the recovery of this population. Nothing is known of its current status or reproductive rate.

\section{Issues}

Although mortalities related to both entanglement and ship strikes have been reported for eastern Gray Whales (Sumich \& Harvey, 1986; Heyning, 1990), the only known issue of potential major concern to this population is the development of a large salt works at one of the major calving lagoons in Baja California. If, like the eastern population, western Gray Whales have a heavy reliance on a highly specific calving habitat (coastal lagoons), they may be highly vulnerable to human activities, notably coastal development. Research to locate these breeding grounds should be considered a priority in the conservation of this population. The most significant impending threat to the remnant Okhotsk Sea population is a major program of oil and gas exploration, which is planned to occur just offshore (and upwind) of major Gray Whale feeding habitat off north-eastern Sakhalin Island (Brownell et al., 1997). The severe earthquake which occurred in the Sakhalin region in May, 1995 has increased fears of an oil-related catastrophe there. Too little is known of the western population to determine whether other problems, such as entanglement, represent significant threats.

\section{Blue Whale Balaenoptera musculus}

Populations at high risk: probably most; known exception is California/eastern North Pacific.

\section{Historical background}

The speed of the Blue Whale kept it largely immune from whaling until the latter part of the last century, when the invention of the steam engine and the explosive harpoon allowed whalers to regularly catch and kill this species for the first time. The introduction of the compressor (allowing inflation of a carcass that would otherwise sink) and the factory ship were also major innovations in the commercial exploitation of this and other rorquals. The Blue Whale subsequently became a principal target of the industry throughout the world, notably following the opening in 1904 of the rich whaling grounds in the Southern Ocean. Approximately 360000 Blue Whales were killed this century in the Antarctic alone (IWC, 1995, pp. 129-130). The Soviets continued extensive exploitation of the species after it was officially protected world-wide in 1967, taking more than 8000 unreported Pygmy Blue Whales (see below) in various locations (Zemsky et al., 1995, 1996; Yablokov etal. 1998 ). 
Biology

Blue Whales are the largest animals on Earth: they can exceed $30 \mathrm{~m}$ in length and weigh close to 200 tons. Subspecific divisions are recognized, with all northern hemisphere animals believed to be Balaenoptera musculus musculus. In the southern hemisphere, the species is divided into the 'true' Blue Whale (B. m. intermedia) and the so-called 'Pygmy' Blue (B. m. brevicauda; Ichihara, 1966). The latter differs markedly in size and morphology from the former, but existing evidence indicates that it may occupy a similar ecological niche. Current data suggest that the range of the Pygmy Blue Whale is the mid-latitude $\left(40-54^{\circ} \mathrm{S}\right)$ waters of the eastern South Atlantic, Indian Ocean and western South Pacific (Ichihara, 1966; Kato, Miyashita \& Shimada, 1995), but the distribution of this subspecies is not fully understood.

Blue Whales have a cosmopolitan distribution, occurring in all oceans, and are found in a variety of habitats from coastal areas to pelagic waters far offshore. Like most rorquals, they are believed to undertake seasonal migrations between high-latitude feeding grounds and breeding areas in the tropics (Mackintosh, 1942). However, the population structure is complex; there is some evidence for year-round occupancy of certain tropical waters (e.g. off western Costa Rica; Reilly \& Thayer, 1990), and it is not clear how migratory behaviour varies among animals of different sex or age classes.

In the North Atlantic, two subpopulations (an eastern and a western) are recognized for the purpose of management (Gambell, 1979; Best, 1993), yet there has been little attempt to investigate whether this view is correct. Whaling and photo-identification data suggest that Blue Whales found off the coasts of Nova Scotia, Newfoundland, the Gulf of St Lawrence and western Greenland belong to the same population (Jonsgård, 1955; F. Larsen, personal communication). The species is rarely found in the shelf waters of the eastern United States (Wenzel, Mattila \& Clapham, 1988). In the North Pacific, whaling and sighting data suggest the existence of at least five subpopulations (reviewed by Reeves et al., 1998). These include California/Mexico, the eastern Gulf of Alaska, the Aleutian Islands (the 'central stock'), northern Japan/Kurils/Kamchatka, and southern Japan. The relationship between the animals from California/Mexico and those observed off Costa Rica is unclear. In the Southern Ocean, there is evidence for the existence of relatively discrete feeding stocks (Mackintosh \& Wheeler, 1929), but the overall population structure in this region is not well understood.

Blue Whales are individually identifiable from the unique pattern of mottling on the animal's body (Sears et al., 1990). Survey coverage of individually identified Blue Whales along the west coast of the continental United States has established migratory connections between this region and waters to the south, including those of Baja California (Calambokidis et al., 1990; Calambokidis \& Steiger, 1995). In addition, recent work has suggested that the west coast population is largely separate from the Blue Whales which feed in the Gulf of Alaska (J. Calambokidis, personal communication). Ongoing genetic studies should help to resolve this and other questions regarding population structure in this species.

Blue Whales are believed to be sexually mature at approximately 5 years, and females reproduce at 2-3-year intervals (Lockyer, 1984). The species is virtually stenophagous on euphausiids throughout its range (Mackintosh, 1942; Gaskin, 1982), although it has been observed feeding on pelagic red crabs, Pleuroncodes planipes, off Baja California (Rice, 1986).

\section{Present status}

Knowledge of Blue Whale populations is often severely limited by their lack of accessibility for research, and we caution that few data are available with which to assess the status of many stocks, notably those in the Southern Ocean. While it is generally accepted that the extensive exploitation to which this species was subject reduced most populations to small fractions of their original sizes, quantitative data with which to estimate current abundance reliably are sparse. 
In the Antarctic, sighting data from circumpolar surveys gave a total population estimate of 710 , but with a large (0.64) coefficient of variation (Butterworth, Borchers \& Chalis, 1993). Although this has been cited by some observers (e.g. Hatanaka \& Komatsu, 1994) as evidence that Antarctic Blue Whale stocks are failing to recover, Gerrodette (1995) emphasized the impossibility of detecting any change in population size from such data given the low statistical power involved. No reliable data exist on Pygmy Blue Whale abundance in any area; Brownell (1995) gives details of Soviet catches of the subspecies and states that the status of both forms must be reconsidered given the extensive underreporting that occurred. As noted elsewhere (Clapham \& Brownell, 1996), the continued whaling-induced decline of these populations, at a time when they were thought to be protected, underscores Gerrodette's point that detection of any change in a small population would require unrealistic levels of survey effort. Thus a reliable assessment of Antarctic Blue Whales (both the 'true' and pygmy forms) is impossible at this time; we can say only that existing data indicate that the population(s) remain small, and should be provisionally ranked among the most endangered baleen whale stocks.

Of the various other populations of Blue Whales (of either type), the only one which appears to be recovering strongly from exploitation is that of the eastern North Pacific, which feeds off California and probably breeds in tropical or equatorial waters to the south (Calambokidis et al., 1990). Estimates of abundance for this population, derived from both individual identification and linetransect surveys, are approximately 2000 animals, with a trend towards increasing size over several years (Barlow, 1995; Calambokidis \& Steiger, 1995). However, it is possible that part of this increase is related to a prey-related shift in distribution inshore (Calambokidis, 1995).

There are no reliable estimates of abundance for the other four putative North Pacific stocks. However, that from southern Japan appears to have been extirpated by intensive shore-based whaling (Kasaharu, 1950). Furthermore, sighting surveys suggest that Blue Whales are now rare in areas of former abundance in the Aleutian Islands and eastern Gulf of Alaska, a phenomenon that is presumably also attributable to overexploitation (Stewart et al., 1987; Reeves et al., 1997). The status of the north-western North Pacific stock is unknown, but recent surveys have found Blue Whales in offshore areas south-east of Kamchatka (Y. Fujise et al., paper SC/47/NP3 presented to the International Whaling Commission Scientific Committee, May 1995 unpublished data).

In the North Atlantic, a long-term study by Sears et al. (1990) identified 203 individual Blue Whales in the Gulf of St Lawrence. These data could not be used to estimate abundance (Hammond, Sears \& Bérubé, 1990), but all indications are that the population to which these belong is small. Estimates for the current size of the eastern stock range from a maximum of 442 whales (Gunnlaugsson \& Sigurjónsson, 1990) to 1000-2000 with no details given (Sigurjónsson, 1995), but again survey coverage has been insufficient to yield reliable data.

It is not known whether the Blue Whales found in the north-western Indian Ocean and Arabian Sea region constitute a separate population that resides in tropical waters year-round, as is the case with the Humpback Whales found there (Mikhalev, 1997). It is possible that this stock is small, but there is very little information from this area; however, impending analysis of illegal Soviet catch data (Y. A. Mikhalev, unpublished data) may shed light on the Blue Whales of this region.

Issues

Currently, there are no known major anthropogenic threats to Blue Whale populations. Ship strikes involving this species are known off California (Barlow et al., 1995), but the magnitude of this problem is unknown. If this whale is indeed failing to recover in certain areas, it may be primarily because of the various problems associated with small population size. As we note above, the wideranging behaviour and inaccessibility of the Blue Whale, notably in the Southern Ocean, has always made research on this species very difficult. This is regrettable, as an assessment of its status is 
urgently required, particularly in the southern hemisphere where the population was drastically reduced by decades of poorly managed and sometimes illegal whaling. The contention that Blue Whale recovery in the Antarctic is being inhibited by prey competition from Minke Whales (e.g. IWC, 1994; p. 102) has little basis in existing data (Clapham \& Brownell, 1996). Finally, although the Blue Whale's dependence upon a single food source (krill) is somewhat offset by the latter's great abundance, this stenophagy would make the species more vulnerable in the event of a major decline in prey. Human overexploitation of Antarctic krill stocks, or declines due to global climatic changes (Loeb et al., 1997) could precipitate such a problem, but at least the former does not appear likely in the foreseeable future. A Recovery Plan for the Blue Whale in US waters has been produced by the US National Marine Fisheries Service (Reeves et al., 1998).

\section{OTHER SPECIES}

\section{Humpback Whale Megaptera novaeangliae}

The Humpback Whale is arguably the best-known of all the baleen whales: its frequently coastal distribution, and the ease with which individuals can be identified from natural markings (Katona \& Whitehead, 1981) have made it the focus of several long-term studies. It is found in all oceans of the world; the southern hemisphere populations (traditionally divided for management purposes into five or six stocks, or areas; see Mackintosh, 1942) together possess a circumpolar distribution. Humpback Whales undertake often very long migrations from summer feeding grounds to tropical breeding and calving areas in winter (Stone, Flórez-González \& Katona, 1990; Palsbøll et al., 1997), where they typically concentrate around reefs or islands.

A coastal species over much of its extensive world-wide range, the Humpback Whale bore the initial brunt of whaling activities in many areas. Often the first species to be taken, it was frequently hunted to commercial extinction, after which whalers switched to other whales (Tønnessen \& Johnsen, 1982; Clapham et al., 1997). Hundreds of thousands of Humpback Whales were killed this century throughout much of their range, notably in the Southern Ocean. Indeed, Humpback Whales were the most frequent target of the recently disclosed illegal catches by the Soviet Union. Although the USSR reported taking only 2710 Humpback Whales in the Antarctic, the actual total was in excess of 48000 (Zemsky et al., 1995; Yablok et al., 1998). Overall, it is not unlikely that many Humpback Whale populations were reduced by more than $90 \%$ of their original size.

In spite of its catch history, the Humpback Whale appears to be a remarkably resilient species. The well-studied population in the North Atlantic was recently estimated from photo-ID data at 10600 (95\% CI 9300-12 100) (Smith et al., 1999). An estimate from genetic tagging data gave 4894 males (95\% CI 3374-7123) and 2804 females (95\% CI 1776-4463) (Palsbøll et al., 1997); because these latter data suggest that a substantial proportion of females were unavailable for sampling in the West Indies study area, this is very likely to be an underestimate of the overall North Atlantic population. A growth rate for the Gulf of Maine feeding stock was estimated at $6.5 \%$ per annum ( $\mathrm{SE}=0.012$; Barlow \& Clapham, 1997). What was considered a 'remnant' population in the eastern North Atlantic has proved to be of substantial size (Øien, 1990), although the species is rare in some probable former habitats such as the British Isles. The Cape Verde Islands, once important as a whaling ground in the mid-1800s, appear to host relatively few Humpback Whales today, although research in this region has begun only recently (Reiner, Dos Santos \& Wenzel, 1996).

The eastern North Pacific population, which feeds along the coasts of California, Oregon and Washington and breeds in Mexican waters, has been estimated from mark-recapture data at approximately 600 animals (Calambokidis \& Steiger, 1995), although analysis of historical whaling data suggests that this stock is well below its pre-exploitation size (Clapham et al., 1997). Baker \& Herman (1987) give a mark-recapture estimate of 1407 whales (95\% CI 1113-1701) for the breeding range in Hawaiian waters, an area which is used by whales feeding primarily off Alaska (Perry, 
Baker \& Herman, 1990). Cerchio (1994) presented new analyses of data from Hawaii, together with a critique of various mark-recapture methods. He concluded that most estimates were subject to low precision and/or bias, and thus that the population size could be anywhere from 2000 to 5000 animals. The status of the western North Pacific population is unknown, although some research has begun in the region in recent years (Darling \& Mori, 1993). The only basin-wide estimate currently available is that by Calambokidis et al. (1997), who used mark-recapture techniques to estimate between 6000 and 8000 animals for all known North Pacific wintering areas.

The status of the southern hemisphere populations is unclear. Data from Australia, the western Indian Ocean and western South America suggest that recovery is occurring in those populations which have been the focus of recent survey effort (Bannister, Kirkwood \& Wayte, 1991; FlórezGonzález, 1991; Findlay et al., 1994; Paterson, Paterson \& Cato, 1994). However, Best (1993) notes that no significant increase is apparent among the Humpback Whale population that migrates past New Zealand to Tonga, where a substantial native fishery persisted until 1978.

Overall, the biology and catch history of this whale leads us to the subjective assertion that Humpback Whales, given time, will recover well throughout their range. However, some populations merit close attention; two examples are those off California and off New Zealand/ Tonga, as noted. Another population worthy of conservation assessment is that inhabiting the Arabian Sea. This group is unique for the species in that the animals both feed and breed in tropical waters, remaining in low latitudes year-round (Mikhalev, 1997). Little is known of the population today, although it was recently disclosed that the Soviets killed 238 Humpback Whales in 10 days in this region in 1966 (Mikhalev, 1997). The impact of this catch on what may have been a small stock is unclear; research here would be of considerable value, particularly as entanglement in fishing gear is known to be an issue for this population (M. Al-Barwani, personal communication).

\section{Southern Right Whale Eubalaena australis}

Like most southern hemisphere baleen whales, Southern Right Whales have a circumpolar distribution, although their population structure and the degree of exchange between putative stocks is unclear. At least some of the various recognized populations spend part of the year in inshore waters off the coasts of South America, South Africa and Australia. The range of others includes a variety of offshore island areas (e.g. Crozet and Kerguelen) whose remoteness has precluded systematic study (Best, 1993). Like the Northern Right Whale, the species is highly migratory.

Southern Right Whales were extensively exploited in this and previous centuries. Best (1987) used American import records for whale oil and baleen to estimate that almost 60000 Southern Right Whales were killed by American whalers alone during the nineteenth century. The Soviet illegal catches included a take of 3212 Southern Right Whales (only four of which were reported to the IWC) between 1951 and 1970 (Tormosov et al., 1998; Yablokov et al., 1998).

Four populations of Southern Right Whales have been the focus of long-term research efforts (western Australia, eastern South America, and the eastern and western coasts of southern Africa), and all have exhibited apparent annual rates of increase ranging from about 6-14\% over various periods of study (Payne et al., 1990; Best, 1990, 1993; Bannister, 1991). Observations from Brazil and Chile suggest that a slow recovery is also taking place in these areas (Best, 1993). With the exception of Campbell Island south of New Zealand, where recent work has found substantial numbers of whales (Patenaude, Baker \& Gates, 1998), the status of the Southern Right Whale populations around remote islands is unknown.

\section{OTHER ISSUES}

\section{Small population problems and extinction-proneness}

In addition to the specific issues outlined above, we must also consider some of the natural (nonanthropogenic) factors which influence the recovery or decline of a population that has been 
reduced to a small size. The vulnerability and recovery potential of an endangered species are in part contingent upon fundamental characteristics of its ecology and life history. From studies of terrestrial mammals and birds, it is now recognized that ecological correlates of 'extinction-proneness' exist in a wide range of taxa (Ehrenfeld, 1970; Terborgh, 1974; Pimm, Jones \& Diamond, 1988; Laurance, 1991). A brief consideration is given below of those risk factors that are arguably relevant to baleen whales.

The species exists in one or a few populations. Such species are particularly vulnerable because catastrophic events such as epidemics or habitat loss can result in the loss of the remaining population(s) and thus of the species itself. Although most of the species listed in Table 1 fall into this category, this factor is arguably more critical in terrestrial populations of plants or animals, where loss of habitat is a major threat.

The population(s) are small. As is well known, small populations are inherently more vulnerable to stochastic changes in characteristics such as sex ratio or birth rate, since the effects of such changes are often magnified when abundance is low (Gilpin \& Soule, 1986). Similarly, small populations are more likely to be disproportionately affected by catastrophes such as epizootics or habitat loss. There is much debate about minimum viable population size, but little agreement on what this is. Among other things, it is obvious that this will vary from species to species depending upon the particular life history, ecology and mating system of the animal concerned. Small population size is clearly a relevant risk factor for the most endangered whale populations, although the extent and details of the risk are unclear.

The species requires a large home range. This factor relates primarily to habitat loss, and is thus less relevant to whales (despite the often huge ranges which they possess) than to large terrestrial mammals.

The species has a large body size. Large animals require larger home ranges and more food; they are also more vulnerable to hunting. This is partly applicable to baleen whales; certainly the latter problem is relevant. As noted above, home range is less of an issue. It is unclear whether whales are ever food-limited to the point where long-term reproductive success is affected.

The species has a low rate of increase. This is certainly true of baleen whales. It is particularly relevant to Right Whales, which calve at intervals of three or more years (Knowlton et al., 1994), and to Bowheads, which are not sexually mature until they are 15-20 years old (Schell et al., 1989; Koski et al., 1993).

The species is migratory. This factor relates primarily to species which are seasonally dependent upon two or more distinct habitats, the loss of any of which can be devastating; it is particularly well illustrated in the plight of migratory songbirds (Hagan, 1992). This is generally less applicable to baleen whales, although there are at least two possible exceptions. One is the Gray Whale, whose apparent dependence upon coastal lagoons for calving renders it highly vulnerable to habitat loss or exploitation. The other is the western North Atlantic Right Whale population, which calves in the highly trafficked coastal waters of the south-eastern United States.

The species has little genetic variability. It is widely assumed that limited genetic diversity in small populations results in inbreeding depression; this can be manifest as expression of deleterious alleles, or in a reduction of the genetic diversity that would normally provide immunity to epizootics 
or other environmental threats (recently reviewed by Lacy, 1997). None the less, there is little agreement about the specifics of this problem, as exemplified by the recent debate on cheetahs (Acinonyx jubatus; May, 1995). Amos (1996) argues that human exploitation is unlikely to have significantly impacted genetic variability in cetaceans, but also that effects of inbreeding depression may be manifest in populations deemed from their levels of variability to be genetically 'healthy'. Genetic diversity may well be relative; consequently, the critical level (i.e. how little is too little?) for a given species is frequently difficult to assess. Broadly speaking, we can say only that, at least in mammals, low genetic diversity will certainly not assist recovery, and may well impede or doom it if unfavourable stochastic factors exist (Lacy, 1997). A recent study using DNA fingerprinting of 22 individuals has suggested that Northern Right Whales are inbred (Schaeff et al., 1997). However, this cannot be confidently assessed without a larger sample size and additional genetic markers; nor can the effects of potentially low variability be readily determined. Furthermore, as suggested for other species by Lacy (1997), effective management and the reduction of threats to individual survival may reverse a decline even if there is a genetic basis to a population's vulnerability.

The species possesses specialized niche requirements. This generally involves reliance upon either highly restricted habitat or a single source of food. The former is largely irrelevant to baleen whales, although global warming and retreat of sea ice could arguably affect Bowhead Whales, and Gray Whales might be vulnerable to environmental or human threats because of their dependence upon lagoons for calving. Restricted diet is clearly an issue for Northern Right Whales and Blue Whales, whose stenophagy would render them vulnerable to major changes in prey abundance.

The species forms temporary or permanent aggregations. Such aggregations leave a population vulnerable to catastrophic loss. Among the species of whales listed in Table 1, the highest risks exist among Gray and Northern Right Whales. The concentration of Gray Whales in calving lagoons renders them highly vulnerable to pollution or hunting. Because Right Whales frequently aggregate in courtship groups containing anywhere from three to more than 20 animals (and frequently near shipping lanes), the loss of a significant portion of the population to a single ship strike is a not entirely implausible event.

Species which are hunted. With the exception of the Davis Strait/Hudson Bay Bowhead stock, there is no known exploitation of any of the populations listed in Table 1.

Overall, it is clear that many of the above risk factors apply to large whales, although the degree to which they affect recovery is highly debatable. We can say only that the populations listed in Table 1 must be considered particularly vulnerable relative to endangered species which do not possess these characteristics.

\section{Analysis of whaling data}

Of the various scientific events within the field of cetology in recent years, few have been of as much interest as the disclosures concerning extensive illegal whaling by the Soviet Union (Yablokov, 1994). As noted above, the difference between reported and actual Soviet catches in the southern hemisphere alone was over 100000 animals (Zemsky et al., 1995, 1996; Yablokov et al., 1998). Some northern hemisphere data have been published (Mikhaliev, 1997), but most are still being analysed. The disclosures partly explain why some Antarctic whale stocks (such as the Blue Whale) appear to be experiencing limited or no recovery despite a supposed 30-year respite from whaling (Brownell, 1995), and there is no doubt that the new Soviet data will be of considerable value in assessing the conservation status of the various populations concerned. It is to be hoped 
that the political situation in Russia will continue to permit new data to emerge, and that sufficient funding will be available to support continued analysis of this important information.

\section{ACKNOWLEDGEMENTS}

We thank Doug DeMaster, Kathy Ralls, Randy Reeves and Bill Amos for their helpful reviews of this manuscript. Partial support for the writing of this review from the World Wildlife Fund US is gratefully acknowledged.

\section{REFERENCES}

Aguilar, A. (1985) Aboriginal whaling off Pagalu (Equatorial Guinea). Reports of the International Whaling Commission, 35, 385-386.

Aguilar, A. (1986) A review of old Basque whaling and its effect on the right whales (Eubalaena glacialis) of the North Atlantic. Reports of the International Whaling Commission, Special Issue, 10, 191-199.

Aguilar, A. (1987) Using organochlorine pollutants to discriminate marine mammals populations: a review and critique of the methods. Marine Mammal Science, 3, 242-262.

Amos, B. (1996) Levels of genetic variability in cetacean populations have probably changed little as a result of human activities. Reports of the International Whaling Commission, 46, 657-658.

Angliss, R.P., Rugh, D.J., Withrow, D.E. \& Hobbs, R.C. (1995) Evaluations of aerial photogrammetry length measurements of the Bering-Chukchi-Beaufort Seas stock of bowhead whales (Balaena mysticetus). Reports of the International Whaling Commission, 45, 313-324.

Baker, C.S. \& Herman, L.M. (1987) Alternative population estimates of humpback whales (Megaptera novaeangliae) in Hawaiian waters. Canadian Journal of Zoology, 65, 2818-2821.

Baker, C.S. \& Palumbi, S.R. (1994) Which whales are hunted? A molecular genetic approach to monitoring whaling. Science, 265, 1538-1539.

Bannister, J.L. (1991) Report on aerial survey for southern right whales off southern Western Australia 1990. Report to the Australian National Parks and Wildlife Service.

Bannister, J.L., Kirkwood, G.P. \& Wayte, S.E. (1991) Increase in humpback whales off Western Australia. Reports of the International Whaling Commission, 41, 461-465.

Barlow, J. (1995) The abundance of cetaceans in California waters. Part I: ship surveys in summer and fall 1991. Fishery Bulletin, 93, 1-14.

Barlow, J., Brownell, R.L., Jr, DeMaster, D.P., Forney, K.A., Lowry, M.S., Osmek, S., Ragen, T.J., Reeves, R.R. \& \& Small, R.J. (1995) US Pacific Marine Mammal Stock Assessments. NOAA Technical Memorandum NMFSSWFSC-219.

Barlow, J. \& Clapham, P.J. (1997) A new birth-interval approach to estimating demographic parameters of humpback whales. Ecology, 78, 535-546.

Barnes, R.H. (1991) Indigenous whaling and porpoise hunting in Indonesia. United Nations Environment Programme Marine Mammal Technical Reports, 3, 99-106.

Belikov, S.E., Gorbunov, Y.A. \& Shil'nikov, V.I. (1989) Distribution of pinnipedia and cetacea in Soviet Arctic seas and the Bering Sea in winter. Soviet Journal of Marine Biology, 15, 251-257.

Berzin, A.A., Blokhin, S.S., Minakuchi, H., Brownell, R.L. Jr, Burdin, A.M. \& Burkanov, V.N. (1995) Bowhead and gray whale populations in the Okhotsk Sea. In: Proceedings of the Workshop on the Okhotsk Sea and Adjacent Areas, 19-24 June, Vladivostok, Russia (abstract). North Pacific Marine Science Organization (PICES), pp. 4445.

Berzin, A.A., Vladimirov, V.L. \& Doroschenko, N.V. (1986) Cetaceans in the coastal waters of the Okhotsk Sea: results from aerial surveys. Reports of the International Whaling Commission, 36, 395-398.

Berzin, A.A., Vladimirov, V.L. \& Doroschenko, N.V. (1990) Aerial surveys to determine the distribution and number of polar whales and beluga whales in the Sea of Okhotsk in 1985-89. In: Questions Relating to the Rational Exploitation of Marine Mammals in the Far Eastern Seas, Vol. 112 (Ed. by A. A. Berzin), pp. 22-34. TINRO, Vladivostock, USSR [Environment Canada Translation 4083779 ].

Best, P.B. (1977) Two allopatric forms of Bryde's whale off South Africa. Reports of the International Whaling Commission, Special Issue, 1, 10-35.

Best, P.B. (1987) Estimates of the landed catch of right (and other whalebone) whales in the American fishery. 18051909. Fishery Bulletin, 85, 403-418.

Best, P.B. (1990) Trends in the inshore right whale population off South Africa. Marine Mammal Science, 6, 93-108.

Best, P.B. (1993) Increase rates in severely depleted stocks of baleen whales. ICES Journal of Marine Science, $\mathbf{5 0 ,}$ $169-186$.

Blokhin, S.A., Maminov, M.K. \& Kosygin, G.M. (1985) On the Korean-Okhotsk population of gray whales. Reports of the International Whaling Commission, 35, 375-376. 
Bockstoce, J.R. \& Burns, J.J. (1993) Commercial whaling in the North Pacific sector. In: The Bowhead Whale (Ed. by J. J. Burns, J. J. Montague \& C. J. Cowles), pp. 563-577. Society for Marine Mammalogy Special Publication number 2, Lawrence, Kansas.

Bowen, S.L. (1974) Possible extinction of the Korean stock of the gray whale (Eschrichtius robustus). Journal of Mammalogy, 55, 208-209.

Brown, S.G. (1986) Twentieth century records of right whales (Eubalaena glacialis) in the northeast Atlantic Ocean. Reports of the International Whaling Commission, Special Issue, 10, 121-127.

Brown, B.E. \& Halliday, R.G. (1983) Fisheries resources of the Northwest Atlantic: some responses to extreme fishing perturbations. In: Proceedings of the Expert Consultation to Examine Changes in Abundance and Species Composition of Neritic Fish Resources (Ed. by E. Por). Food \& Agricultural Organization Fisheries Reports, no. 291.

Brown, M.W., Kraus, S.D., Gaskin, D.E. \& White, B.N. (1994) Sexual composition and analysis of reproductive females in the North Atlantic right whale (Eubalaena glacialis) population. Marine Mammal Science, 10, 253265.

Brownell, R.L. Jr (1995) Japanese and Soviet exploitation of pygmy blue whales. IBI Reports, 5, 25-29.

Brownell, R.L. Jr, Best, P.B. \& Prescott, J.H., eds. (1986) Right whales: past and present status. Reports of the International Whaling Commission, Special Issue, 10, 289 pp.

Brownell, R.L. Jr, Burdin, A.M., Blokin, S.A. \& Berzin, A.A. (1997) Observations on bowhead whales (Balaena mysticetus) in the Shantar Archipelago, western Okhotsk Sea. IBI Reports, 7, 1-7.

Brownell, R.L. Jr \& Chun, C. (1977) Probable existence of the Korean stock of gray whales (Eschrichtius robustus). Journal of Mammalogy, 58, 237-239.

Brownell, R.L. Jr, Clapham, P.J., Kasuya, T. \& Miyashita, T. (1999) Conservation status of North Pacific right whales. Reports of the International Whaling Commission (in press).

Bryant, P.J. (1995) Dating remains of gray whales from the eastern North Atlantic. Journal of Mammalogy, 76, $857-$ 861.

Burns, J.J., Montague, J.J. \& Cowles, C.J., eds. (1993) The Bowhead Whale. Society for Marine Mammalogy, Special Publication number 2, Lawrence, Kansas.

Butterworth, D.S., Borchers, D.L. \& Chalis, S. (1993) Updates of abundance estimates for Southern Hemisphere blue, fin, sei and humpback whales incorporating data from the second circumpolar set of IDCR cruises. Reports of the International Whaling Commission, 43, 530.

Calambokidis, J. (1995) Blue whales off California. Whalewatcher, 29, 3-7.

Calambokidis, J. \& Steiger, G.H. (1995) Population estimates of humpback and blue whales made through photoidentification from 1993 surveys off California. Final Report to the Southwest Fisheries Science Center, La Jolla, CA 92038.

Calambokidis, J., Steiger, G.H., Cubbage, J.C., Balcomb, K.C., Ewald, C., Kruse, S., Wells, R. \& Sears, R. (1990) Sightings and movements of blue whales off central California 1986-88 from photo-identification of individuals. Reports of the International Whaling Commission, Special Issue, 12, 343-348.

Calambokidis, J., Steiger, G.H., Straley, J.M., Quinn, T.J.I.I., Herman, L.M., Cerchio, S., Salden, D.R., Yamaguchi, M., Sato, F., UUrban, J.R., Jacobsen, J., von Ziegesar, O., Balcomb, K.C., Gabriele, C.M., Dahlheim, M.E., Higashi, N., Uchida, S., Ford, J.K.B., Miyamura, Y., Ladrón de Guevara, P., Mizroch, S.A., Schlender, L. \& Rasmussen, K. (1997) Abundance and population structure of humpback whales in the North Pacific basin. Final Report to the Southwest Fisheries Science Center, La Jolla, CA 92038.

Carretta, J.V., Lynn, M.S. \& LeDuc, C.A. (1994) Right whale (Eubalaena glacialis) sighting off San Clemente Island, California. Marine Mammal Science, 10, 101-105.

Caswell, H., Fujiwara, M. \& Brault, S. (1999) Declining survival probability threatens the North Atlantic right whale. Proceedings of the National Academy of Sciences, USA (in press)

Cerchio, S. (1994) Estimates of humpback whale (Megaptera novaeangliae) abundance off Kauai, Hawaii. 198993, using mark-recapture techniques. Report to the Sanctuaries and Reserves Division, National Oceanic and Atmospheric Administration. Available from Moss Landing Marine Laboratories, Box 450, Moss Landing, CA 95039.

Christensen, I., Haug, T. \& Øien, N. (1992) Seasonal distribution, exploitation and present abundance of stocks of large baleen whales (Mysticeti) and sperm whales (Physeter macrocephalus) in Norwegian and adjacent waters. ICES Journal of Marine Science, 49, 341-355.

Clapham, P.J. \& Brownell, R.L. Jr (1996) Potential for interspecific competition in baleen whales. Reports of the International Whaling Commission, 46, 361-367.

Clapham, P.J. \& Brownell, R.L. Jr (1999) Vulnerability of migratory baleen whales to ecosystem degradation. Convention on Migratory Species, in press.

Clapham, P.J., Leatherwood, S., Szczepaniak, I. \& Brownell, R.L. Jr (1997) Catches of humpback and other whales from shore stations at Moss Landing and Trinidad Bay, California. 1919-26. Marine Mammal Science, 13, 368394. 
Colborn, T. \& Smolen, M. (1996) An epidemiological analysis of persistent organochlorine contaminants in cetaceans. Reiews of Environmental Contamination and Toxicology, 146, 91-172.

Collett, R. (1909) A few notes on the whale Balaena glacialis and its capture in recent years in the North Atlantic by Norwegian whalers. Proceedings of the Zoological Society of London, 1909, 91-98 + 27 plates.

Cosens, S.E., Qamukaq, T., Parker, B., Dueck, L.P. \& Anardjuak, B. (1997) The distribution and numbers of bowhead whales, Balaena mysticetus, in northern Foxe Basin in 1994. Canadian Field Naturalist, 111, 381-388.

Cumbaa, S.L. (1986) Archaeological evidence of the 16th century Basque right whale fishery in Labrador. Reports of the International Whaling Commission, Special Issue, 10, 187-190.

Darling, J.D. \& Mori, K. (1993) Recent observations of humpback whales (Megaptera novaeangliae) in Japanese waters off Ogasawara and Okinawa. Canadian Journal of Zoology, 71, 325-333.

Davis, R.A. \& Koski, W. (1980) Recent observations of the bowhead whale in the eastern Canadian high Arctic. Reports of the International Whaling Commission, 30, 439-444.

Ehrenfeld, D.W. (1970) Biological Conservation. Holt, Rinehart \& Winston, New York.

Findlay, K.P., Best, P.B., Peddemors, V.M. \& Gove, D. (1994) The distribution and abundance of humpback whales on their southern and central Mozambique winter grounds. Reports of the International Whaling Commission, 44, 311-320.

Finley, K.J. (1990) Isabella Bay, Baffin Island: an important historical and present-day concentration area for the endangered bowhead whale (Balaena mysticetus) of the eastern Canadian Arctic. Arctic, 43, 137-152.

Flórez-González, L. (1991) Humpback whales Megaptera novaeangliae in the Gorgona Island, Colombian Pacific breeding waters: population and pod characteristics. Memoirs of the Queensland Museum, 30, 291-295.

Gambell, R. (1979) The blue whale. Biologist, 26, 209-215.

Gaskin, D.E. (1982) The Ecology of Whales and Dolphins. Heinemann Press, London.

George, J.C., Suydam, R.S., Philo, L.M., Albert, T.F., Zeh, J.E. \& Carroll, G.M. (1995) Report of the spring 1993 census of bowhead whales, Balaena mysticetus, off Point Barrow, Alaska, with observations on the 1993 subsistence hunt of bowhead whales by Alaska Eskimos. Reports of the International Whaling Commission, 45, 371-384.

Geraci, J.R. (1990) Physiologic and toxic effects of oil on cetaceans. In: Sea Mammals and Oil: Confronting the Risks (Ed. by J. R. Geraci \& D. J. St Aubin), pp. 167-197. Academic Press, San Diego, California.

Geraci, J.R., Anderson, D.M., Timperi, R.J., St. Aubin, D.J., Early, G.A., Prescott, J.H. \& Mayo, C.A. (1989) Humpback whales (Megaptera novaeangliae) fatally poisoned by dinoflagellate toxins. Canadian Journal of Fisheries and Aquatic Science, 46, 1895-1898.

Geraci, J.R. \& St. Aubin, D.J. (1980) Offshore petroleum resource development and marine mammals: a review and research recommendations. Marine Fisheries Review, 42, 1-12.

Gerrodette, T. (1995) The ability of IDCR cruises to detect changes in blue whale population size. Reports of the International Whaling Commission, 45, 271-272.

Gilpin, M.E. \& Soule, M.E. (1986) Minimum viable population: processes of species extinctions. In: Conservation Biology (Ed. by M. Soule), pp. 19-34. Sinauer, New York.

Glockner-Ferrari, D.A. \& Ferrari, M.J. (1990) Reproduction in the humpback whale (Megaptera novaeangliae) in Hawaiian waters. 1975-88: the life history, reproductive rates and behaviour of known individuals identified through surface and underwater photography. Reports of the International Whaling Commission, Special Issue, 12, 161-169.

Goddard, P.D. \& Rugh, D.J. (1998) Right whale (Eubalaena glacialis) sighting in the Bering Sea in July 1996. Marine Mammal Science, 14, in press.

Gunnlaugsson, T. \& Sigurjónsson, J. (1990) NASS-87: estimation of whale abundance based on observations made on board Icelandic and Faroese survey vessels. Reports of the International Whaling Commission, 40, 571-580.

Hagan, J. (ed.) (1992) Neotropical Migrants. Smithsonian Institution Press, Washington, DC.

Hamilton, P.K., Knowlton, A.R., Marx, M.K. \& Kraus, S.D. (1998) Age structure and longevity in North Atlantic right whales (Eubalaena glacialis) and their relation to reproduction. Marine Ecology Progress Series, 171, 285292.

Hammond, P.S., Sears, R. \& Bérubé, M. (1990) A note on problems in estimating the number of blue whales in the Gulf of St Lawrence from photo-identification data. Reports of the International Whaling Commission, Special Issue, 12, 141-142.

Hatanaka, H. \& Komatsu, M. (1994) International action plan for recovery of large whales: toward recovery of blue whales. Reports of the International Whaling Commission, 44, 515.

Henderson, D.A. (1984) Nineteenth century gray whaling: grounds, catches and kills, practices and depletion of the gray whale population. In: The Gray Whale (Ed. by M. L. Jones, S. L. Swartz, \&, S. Leatherwood), pp. 159-186. Academic Press, New York.

Henderson, D.A. (1990) Gray whales and whalers on the China coast in 1869. Whalewatcher, 24, 14-16.

Heyning, J.E. (1990) Entanglements of baleen whales in fishing gear off southern California. Reports of the International Whaling Commission, 40, 427-431. 
Ichihara, T. (1966) The pygmy blue whale, Balaenoptera musculus brevicauda, a new subspecies from the Antarctic. In: Whales, Dolphins and Porpoises (Ed. by K. S. Norris), pp. 79-113. University of California Press, Berkeley, California.

IWC (1994) Review of food and feeding habits of Southern Hemisphere baleen whales. Reports of the International Whaling Commission, 44, 102.

IWC (1995) Forty-Fifth Report of the International Whaling Commission. Reports of the International Whaling Commission, 45.

IWC (1996) Forty-Sixth Report of the International Whaling Commission. Reports of the International Whaling Commission, 46.

Jones, M.L., Swartz, S.L. \& Leatherwood, S. (eds) (1984) The Gray Whale. Academic Press, New York.

Jonsgård, Å. (1955) The stocks of blue whales (Balaenoptera musculus) in the northern Atlantic Ocean and adjacent Arctic waters. Norsk Hvalfangsttidende, 44, 297-311.

Kasaharu, A. (1950) Whaling and its resources in the Japanese coastal waters. Bull. Res. Inst. Nikon Suisan Co. Ltd., Number 4. +95 figures [in Japanese].

Kato, H. \& Kasuya, T. (1997) Catch history of the Asian stock of gray whales by modern whaling with some notes on migrations. Reports of the International Whaling Commission, Special Issue, 17, in press.

Kato, H., Miyashita, T. \& Shimada, H. (1995) Segregation of the two sub-species of the blue whale in the Southern Hemisphere. Reports of the International Whaling Commission, 45, 273-283.

Katona, S.K. \& Whitehead, H.P. (1981) Identifying humpback whales using their natural markings. Polar Record, 20, 439-444.

Kellogg, R. (1929) What is known of the migration of some of the whalebone whales. Smithsonian Institution Annual Reports, pp. 467-494.

Kenney, R.D., Winn, H.E. \& Macauley, M.C. (1994) Cetaceans in the Great South Channel. 1979-89: right whale (Eubalaena glacialis). Continental Shelf Research, 15, 385-414.

Kihlström, J.E., Olsson, M., Jensen, S., Johansson, A., Ahlbom, J. \& Bergman, A. (1992) Effects of PCB and different fractions of PCB on the reproduction of the mink (Mustela vison). Ambio, 21, 563-569.

Knowlton, A.R., Kraus, S.D. \& Kenney, R.D. (1994) Reproduction in North Atlantic right whales (Eubalaena glacialis). Canadian Journal of Zoology, 72, 1297-1305.

Kornev, S.I. (1994) A note on the death of a right whale (Eubalaena glacialis) off Cape Lopatka (Kamchatka). Reports of the International Whaling Commission, Special Issue, 15, 443-444.

Koski, W.R., Davis, R.A., Miller, G.W. \& Withrow, D.E. (1993) Reproduction. In: The Bowhead Whale (Ed. by J. J. Burns, J. J. Montague \& C. J. Cowles), pp. 239-274. Society for Marine Mammalogy Special Publication number 2, Lawrence, Kansas.

Kraus, S.D. (1990) Rates and potential causes of mortality in North Atlantic right whales (Eubalaena glacialis). Marine Mammal Science, 6, 278-291.

Kraus, S.D., Moore, K.E., Price, C.E., Crone, M.J., Watkins, W.A., Winn, H.E. \& Prescott, J.H. (1986) The use of photographs to identify individual North Atlantic right whales (Eubalaena glacialis). Reports of the International Whaling Commission, Special Issue, 10, 145-151.

Kraus, S.D., Prescott, J.H., Knowlton, A.R. \& Stone, G.S. (1986) Migration and calving of right whales (Eubalaena glacialis) in the western North Atlantic. Reports of the International Whaling Commission, Special Issue, 10, 139-144.

Lacy, R.C. (1997) Importance of genetic variation to the viability of mammalian populations. Journal of Mammalogy, 78, 320-335.

Laurance, W.F. (1991) Ecological correlates of extinction proneness in Australian tropical rain forest mammals. Conservation Biology, 5, 79-89.

Leatherwood, S. \& Reeves, R.R. (1983) The Sierra Club Handbook of Whales and Dolphins. Sierra Club Books, San Francisco, California.

Lien, J. (1994) Entanglement of large cetaceans in passive inshore gear in Newfoundland and Labrador (1979-90). Reports of the International Whaling Commission, Special Issue, 15, 149-157.

Lockyer, C.L. (1984) Review of baleen whale (Mysticeti) reproduction and implications for management. Reports of the International Whaling Commission, Special Issue, 6, 27-48.

Loeb, V., Siegel, V., Holm-Hansen, O., Hewitt, R., Fraser, W., Trivelpiece, W. \& Trivel piece, S. (1997) Effects of sea-ice extent and krill or salp dominance on the Antarctic food web. Nature London, 387, 897-900.

Loughlin, T.R. (1994a) Marine Mammals and the Exxon Valdez. Academic Press, New York.

Loughlin, T.R. (1994b) Tissue hydrocarbon levels and the number of cetaceans found dead after the spill. In: Marine Mammals and the Exxon Valdez (Ed. by T. R. Loughlin), pp. 359-370. Academic Press, New York.

Lowry, L.F. (1993) Foods and feeding ecology. In: The Bowhead Whale (Ed. by J. J. Burns, J. J. Montague, \&, C. J. Cowles), pp. 201-238. Society for Marine Mammalogy Special Publication number 2, Lawrence, Kansas.

Mackintosh, N.A. (1942) The southern stocks of whalebone whales. Discovery Reports, 22, 197-300.

Mackintosh, N.A. \& Wheeler, J.F.G. (1929) Southern blue and fin whales. Discovery Reports, 1, 257-540. 
McQuaid, C.D. (1986) Post-1980 sightings of bowhead whales (Balaena mysticetus) from the Spitsbergen stock. Marine Mammal Science, 2, 316-318.

Malme, C.I., Miles, P.R., Clark, C.W., Tyack. P. \& Bird, J.E. (1983) Investigations of the potential effects of underwater noise from petroleum industry activities on migrating gray whale behavior. Bolt, Beranek and Newman report number 5366 submitted to Minerals Management Service, US Dept. of Interior.

Mate, B.R. \& Harvey, J.T. (1984) Ocean movements of radio-tagged gray whales. In: The Gray Whale (Ed. by M. L. Jones, S. L. Swartz \& S. Leatherwood), pp. 577-589. Academic Press, New York.

May, R. (1995) The cheetah controversy. Nature, London, 374, 309-310.

Mayo, C.A. \& Marx, M.K. (1989) Surface foraging behavior of the North Atlantic right whale, Eubalaena glacialis, and associated zooplankton characteristics. Canadian Journal of Zoology, 68, 2214-2220.

Mead, J.G. \& Brownell, R.L. Jr (1993) Order Cetacea. In: Mammal Species of the World (Ed. by D. E. Wilson \& D. M. Reeder), pp. 349-364. Smithsonian Institution Press, Washington, DC.

Mead, J.G. \& Mitchell, E.D. (1984) Atlantic gray whales. In: The Gray Whale (Ed. by M. L. Jones, S. L. Swartz \& S. Leatherwood), pp. 33-53. Academic Press, New York.

Mikhalev, Y.A. (1997) Humpback whales Megaptera novaeangliae in the Arabian Sea. Marine Ecology Progress Series, 149, 13-21.

Montague, J.J. (1993) Introduction. In: The Bowhead Whale (Ed. by J. J. Burns, J. J. Montague, \&, C. J. Cowles), pp. 1-21. Society for Marine Mammalogy Special Publication number 2, Lawrence, Kansas.

Moore, S.E. \& Reeves, R.R. (1993) Distribution and movement. In: The Bowhead Whale (Ed. by J. J. Burns, J. J. Montague, \&, C. J. Cowles), pp. 313-386. Society for Marine Mammalogy Special Publication number 2, Lawrence, Kansas.

Mori, K. (1991) Ogasawara Whale Watching Guide. Diver [in Japanese].

National Marine Fisheries Service. (1991) Recovery Plan for the Northern Right Whale (Eubalaena Glacialis). Prepared by the Right Whale Recovery Team for the National Marine Fisheries Service, Silver Spring, Maryland 20910.

Nerini, M. (1984) A review of gray whale feeding ecology. In: The Gray Whale (Ed. by M. L. Jones, S. L. Swartz \& S. Leatherwood), pp. 423-450. Academic Press, New York.

Nerini, M.K., Braham, H.W., Marquette, W.M. \& Rugh, D.J. (1984) Life history of the bowhead whale, Balaena mysticetus (Mammalia: Cetacea). Journal of Zoology London, 204, 443-468.

O'Shea, T.J. \& Brownell, R.L. Jr (1994) Organochlorine and metal contaminants in baleen whales: a review and evaluation of conservation implications. Science of the Total Environment, 154, 179-200.

Øien, N. (1990) Sighting surveys in the northeast Atlantic in July 1988: distribution and abundance of cetaceans. Reports of the International Whaling Commission, 40, 599-511.

Omura, H. (1958) North Pacific right whale. Scientific Reports of the Whales Research Instiute, 13, 1-52.

Omura, H. (1986) History of right whale catches in the waters around Japan. Reports of the International Whaling Commission, Special Issue, 10, 35-41.

Palsbøll, P.J., Allen, J., Bérubé, M., Clapham, P.J., Feddersen, T.P., Hammond, P., Jørgensen, H., Katona, S., Larsen, A.H., Larsen, F., Lien, J., Mattila, D.K., Sigurjónsson, J., Sears, R., Smith, T., Sponer, R., Stevick, P. \& Øien, N. (1997) Genetic tagging of humpback whales. Nature London, 388, 767-769.

Patenaude, N.J., Baker, C.S. \&Gales, N.J. (1998) Observations of southern right whales on New Zealand's subantartic wintering grounds. Marine Mammal Science, 14, 350-355.

Paterson, R., Paterson, P. \& Cato, D.H. (1994) The status of humpback whales Megaptera novaeangliae in East Australia thirty years after whaling. Biological Conservation, 70, 135-142.

Payne, R., Rowntree, V., Perkins, J.S., Cooke, J.G. \& Lankester, K. (1990) Population size, trends and reproductive parameters of right whales (Eubalaena australis) off Peninsula Valdes, Argentina. Reports of the International Whaling Commission, Special Issue, 12, 271-278.

Payne, P.M., Wiley, D.N., Young, S.B., Pittman, S., Clapham, P.J. \& Jossi, J.W. (1990) Recent fluctuations in the abundance of baleen whales in the southern Gulf of Maine in relation to changes in selected prey. Fishery Bulletin, 88, 687-696.

Perrin, W.F., Donovan, G. \& Barlow, J., eds. (1994) Gill nets and cetaceans. Reports of the International Whaling Commission, Special Issue, 15.

Perry, A., Baker, C.S. \& Herman, L.M. (1990) Population characteristics of individually identified humpback whales in the central and eastern North Pacific: a summary and critique. Reports of the International Whaling Commission, Special Issue, 12, 307-317.

Pimm, S.L., Jones, H.L. \& Diamond, J. (1988) On the risk of extinction. American Naturalist, 132, 757-785.

Ralls, K. (1976) Mammals in which females are larger than males. Quarterly Review of Biology, 51, 245-270.

Reeves, R.R. (1984) Modern commercial pelagic whaling for gray whales. In: The Gray Whale (Ed. by M. L. Jones, S. L. Swartz \& S. Leatherwood), pp. 187-200. Academic Press, New York.

Reeves, R.R., Clapham, P.J., Brownell, R.L. Jr \& Silber, G.K. (1998) Recovery Plan for the blue whale, Balaenoptera musculus. National Marine Fisheries Service, Silver Spring, Maryland 20910. 
Reeves, R.R. \& Mitchell, E. (1986) American pelagic whaling for right whales in the North Atlantic. Reports of the International Whaling Commission, Special Issue, 10, 221-254.

Reeves, R.R. \& Mitchell, E. (1990) Bowhead whales in Hudson Bay, Hudson Strait, and Foxe basin: a review. Le Naturalist Canadien, 117, 25-43.

Reeves, R., Mitchell, E., Mansfield, A. \& McLaughlin, M. (1983) Distribution and migration of the bowhead whale, Balaena mysticetus, in the eastern North American Arctic. Arctic, 36, 5-64.

Reilly, S.B. (1992) Population biology and status of eastern Pacific gray whales: recent developments. In: Wildlife 2001: Populations (Ed. by D. R. McCullough \& R. H. Barrett), pp. 1062-1074. Elsevier Applied Science, New York.

Reilly, S.B. \& Thayer, V.G. (1990) Blue whale (Balaneoptera musculus) distribution in the eastern tropical Pacific. Marine Mammal Science, 6, 265-277.

Reiner, F., Dos Santos, M.E. \& Wenzel, F.W. (1996) Cetaceans of the Cape Verde archipelago. Marine Mammal Science, 12, 434-443.

Rice, D.W. (1983) Gestation period and fetal growth of the grey whale. Reports of the International Whaling Commission, 33, 549-544.

Rice, D.W. (1986) Blue whale. In: Marine Mammals of Eastern North Pacific and Arctic Waters (Ed. by D. Haley), pp. 40-45, 2nd edn. Pacific Search Press, Seattle, Washington.

Rice, D.W. \& Wolman, A.A. (1971) The life history and ecology of the gray whale (Eschrichtius robustus). American Society of Mammalogists, Special Publication 3.

Rosenbaum, H.C., Egan, M., Clapham, P.J., Brownell, R.L. Jr \& DeSalle, R. (1997) An effective method for isolating DNA from historical specimens of baleen. Molecular Ecology, 6, 677-681.

Rosenbaum, H.C., Egan, M.G., Clapham, P.J., Brownell, R.L. Jr, Malik, S., Brown, M., White, B. \& DeSalle, R. (1998) Levels of historic genetic diversity and population structure in North Atlantic right whales detected by an effective technique to isolate DNA from museum specimens. In: Proceedings of the Twelfth Biennial Conference on the Biology of Marine Mammals (Abstract),p. 117 Society for Marine Mammalogy, Lawrence Kansas.

Ross, W.G. (1993) Commercial whaling in the North Atlantic sector. In: The Bowhead Whale (Ed. by J. J. Burns, J. J. Montague \& C. J. Cowles), pp. 511-561. Society for Marine Mammalogy Special Publication number 2, Lawrence, Kansas.

Rowntree, V., Darling, J.D., Silber, G. \& Ferrari, M. (1980) Rare sighting of a right whale (Eubalaena glacialis) in Hawaii. Canadian Journal of Zoology, 58, 309-312.

Sayers, H. (1984) Shore whaling for gray whales along the coast of the Californias. In: The Gray Whale (Ed. by M. L. Jones, S. L. Swartz \& S. Leatherwood), pp. 121-157. Academic Press, New York.

Scarff, J.E. (1986) Historic and present distribution of the right whale (Eubalaena glacialis) in the eastern North Pacific south of $50^{\circ} \mathrm{N}$ and east of $180^{\circ} \mathrm{W}$. Reports of the International Whaling Commission, Special Issue, 10, 43-63.

Scarff, J.E. (1991) Historic distribution and abundance of the right whale (Eubalaena glacialis) in the North Pacific, Bering Sea, Sea of Okhotsk and Sea of Japan from the Maury whale charts. Reports of the International Whaling Commission, 41, 467-489.

Schaeff, C., Kraus, S., Brown, M., Perkins, J., Payne, R., Gaskin, D., Boag, P. \& White, B. (1991) Preliminary analysis of mitochondrial DNA variation within and between the right whale species (Eubalaena glacialis and Eubalaena australis). Reports of the International Whaling Commission, Special Issue, 13, 217-223.

Schaeff, C.M., Kraus, S.D., Brown, M.W., Perkins, J.S., Payne, R. \& White, B.N. (1997) Comparison of genetic variability of North and South Atlantic right whales (Eubalaena), using DNA fingerprinting. Canadian Journal of Zoology, 75, 1073-1080.

Schaeff, C.M., Kraus, S.D., Brown, M.W. \& White, B.N. (1993) Assessment of the population structure of western North Atlantic right whales (Eubalaena glacialis) based on sighting and mtDNA data. Canadian Journal of Zoology, 71, 339-345.

Schell, D.M., Saupe, S.M. \& Haubenstock, N. (1989) Bowhead whale (Balaena mysticetus) growth and feeding as estimated by ${ }^{13} \mathrm{C}$ techniques. Marine Biology, 103, 433-443.

Sears, R., Williamson, M.J., Wenzel, F.W., Bérubé, M., Gendron, D. \& Jones, P. (1990) Photographic identification of the blue whale (Balaenoptera musculus) in the Gulf of St Lawrence, Canada. Reports of the International Whaling Commission, Special Issue, 12, 335-342.

Seipt, I., Clapham, P.J., Mayo, C.A. \& Hawvermale, M.P. (1990) Population characteristics of fin whales, Balaenoptera physalus, in Massachusetts Bay. Fishery Bulletin, 88, 271-278.

Shelden, K.E.W. \& Rugh, D.J. (1995) The bowhead whale, Balaena mysticetus: its historic and current status. Marine Fisheries Review, 57, 1-20.

Sigurjónsson, J. (1995) On the life history and autecology of North Atlantic rorquals. In: Whales, Seals, Fish and Man (Ed. by A. S. Blix, L. Walløe \& Ø. Ulltang), pp. 425-441. Elsevier Science, New York.

Smith, T.D., Allen, J., Clapham, P.J., Hammond, P.S., Katona, S., Larsen, F., Lien, J., Mattila, D., Palsbøll, P.J., Sigurjósson, J. Stevick, P.T. \& Øien, N. (1999) An ocean-basin wide mark-recapture study of the North Atlantic 
humpback whale (Megaptera novaeangliae). Marine Mammal Science, 15, 1-32.

Stewart, B.S.S.A., Karl, P.K., Yochem, S., Leatherwood, and, J.L. \& Laake. (1987) Aerial surveys for cetaceans in the former Akutan, Alaska, whaling grounds. Arctic, 40, 33-42.

Stoker, S.W. \& Krupnik, I.I. (1993) Subsistence whaling. In: The Bowhead Whale (Ed. by J. J. Burns, J. J. Montague \& C. J. Cowles), pp. 579-629. Society for Marine Mammalogy Special Publication number 2, Lawrence, Kansas.

Stone, G.S., Flórez-González, L. \& Katona, S. (1990) Whale migration record. Nature London, 346, 705.

Sumich, J.L. \& Harvey, J.T. (1986) Juvenile mortality in gray whales (Eschrichtius robustus). Journal of Mammalogy, 67, 179-182.

Suydam, R.S., Angliss, R.P., George, J.C., Braund, S.R. \& DeMaster, D.P. (1995) Revised data on the subsistence harvest of bowhead whales (Balaena mysticetus) by Alaskan eskimos. 1973-93. Reports of the International Whaling Commission, 45, 335-338.

Terborgh, J. (1974) Preservation of natural diversity: the problem of exinction-prone species. Bioscience, 24, 715722.

Tønnessen, J.N. \& Johnsen, A.O. (1982) The History of Modern Whaling. C. Hurst and Co., London.

Tormosov, D.D., Mikhalev, Y.A., Best, P.B., Zemsky, V.A., Sekiguchi, K. \& Brownell, R.L., Jr (1998) Soviet catches of southern right whales Eubalaena australis 1951-1971. Biological data and conservation implications. Biological Conservation, 86, 185-197.

Vladimirov, V.L. (1994) Recent distribution and abundance level of whales in Russian far-eastern seas. Russian Journal of Marine Biology, 20, 1-9.

Volgenau, L., Kraus, S.D. \& Lien, J. (1995) The impact of entanglements on two substocks of the western North Atlantic humpback whale (Megaptera novaeangliae). Canadian Journal of Zoology, 73, 1689-1698.

Wada, S. \& Numachi, K.I. (1991) Allozyme analyses of genetic differentiation among the populations and species of the Balaenoptera. Reports of the International Whaling Commission, Special Issue, 13, 125-154.

Weller, D.W., Würzig, B., Burdin, A.M., Bradford, A.L., Blokhin, S.A., Minakudi, H. \& Brownell, R.L. Jr (1999) Seasonal and annual occurrence of western grey whales in the Okhotsk Sea. Marine Mammal Science (in press).

Wenzel, F.W.D.K., Mattila, and, P.J. \& Clapham. (1988) Balaenoptera musculus in the Gulf of Maine. Marine Mammal Science, 4, 172-175.

Winn, H.E., Price, C.A. \& Sorensen, P.W. (1986) The distributional biology of the right whale (Eubalaena glacialis) in the western North Atlantic. Reports of the International Whaling Commission, Special Issue, 10, 129-138.

Wishner, K.F., Schoenherr, J.R., Beardsley, R. \& Chen, C. (1995) Abundance, distribution and population structure of the copepod Calanus finmarchicus in a springtime right whale feeding area in the southwestern Gulf of Maine. Continental Shelf Research, 15, 475-507.

Yablokov, A.V. (1994) Validity of Soviet whaling data. Nature, London, 367, 108.

Yablokov, A.V., Zemsky, V.A., Mikhalev, Y.A., Tormosov, V.V. \& Berzin, A.A. (1998) Data on Soviet whaling in the Antartic in 1947-1972 (population aspects). Russian Journal of Ecology, 29, 38-42.

Zeh, J.E., Clark, C.W., George, J.C., Withrow, D., Carroll, G.M. \& Koski, W.R. (1993) Current population size and dynamics. In: The Bowhead Whale (Ed. by J. J. Burns, J. J. Montague \& C. J. Cowles), pp. 409-489. Society for Marine Mammalogy Special Publication number 2, Lawrence, Kansas.

Zeh, J.E., George, J.C. \& Suydam, R. (1995) Population size and rate of increase. 1978-93, of bowhead whales, Balaena mysticetus. Reports of the International Whaling Commission, 45, 339-344.

Zemsky, V.A., Berzin, A.A., Mikhaliev, Y.A. \& Tormosov, D.D. (1995) Soviet Antarctic pelagic whaling after WWII: review of actual catch data. Reports of the International Whaling Commission, 46, 131-135.

Zemsky, V., Mikhaliev, Y. \& Berzin, A. (1996) Supplementary information about Soviet whaling in the Southern Hemisphere. Reports of the International Whaling Commission, 46, 131-138.

Submitted 20 August 1997; returned for revision 9 February 1998; revision accepted 17 February 1998 